\title{
Pemberdayaan Peternak Sapi Pola Paronisasi melalui Pembuatan Pupuk Bokashi di Desa Oeletsala, Kabupaten Kupang
}

\section{(Empowerment of Cattle Farmer by Paronization System through Making Fertilizer Bokashi in Oeletsala Village, Kupang Regency)}

\author{
Melkianus Dedimus Same Randu ${ }^{1 *}$, Ferdinan Suharjono Suek ${ }^{1}$, I Gusti Komang Oka Wirawan², \\ Agustinus Semang 3 \\ ${ }^{1}$ Program Studi Produksi Ternak Jurusan Peternakan, Politeknik Pertanian Negeri Kupang \\ Jl. Prof. Dr. Herman Yohanes, Kupang, Nusa Tenggara Timur 85011. \\ 2 Program Studi Kesehatan Hewan Jurusan Peternakan, Politeknik Pertanian Negeri Kupang, \\ Jl. Prof. Dr. Herman Yohanes, Kupang, Nusa Tenggara Timur 85011. \\ ${ }^{3}$ Program Studi Teknologi Pakan Ternak Jurusan Peternakan, Politeknik Pertanian Negeri Kupang, \\ Jl. Prof. Dr. Herman Yohanes, Kupang, Nusa Tenggara Timur 85011. \\ ${ }^{*}$ Penulis Korespondensi: deddy_randu@yahoo.co.id \\ Diterima Agustus 2019/Disetujui Desember 2019
}

\begin{abstract}
ABSTRAK
Desa Oeletsala merupakan wilayah di Kabupaten Kupang yang mayoritas masyarakatnya menjalankan usaha penggemukan (paronisasi) ternak sapi Bali. Kegiatan paronisasi dilaksanakan turun-temurun namun kurang mengeksplorasi pemanfaatan limbah ternak (feses) sehingga menimbulkan pencemaran lingkungan dan mendukung populasi lalat sebagai vektor mekanik thelaziasis. Kegiatan pengabdian ini bertujuan meningkatkan pengetahuan dan keterampilan anggota mitra kelompok tani terkait pembuatan pupuk bokashi. Kegiatan pengabdian dilakukan di Kelompok Nij Baki yang memiliki anggota sebanyak 24 orang. Metode pelaksanaan kegiatan meliputi penyuluhan, demonstrasi plot, pendampingan, dan evaluasi. Hasil kegiatan yang dicapai adalah produksi pupuk bokashi sebanyak $300 \mathrm{~kg}$ dan penerimaan dari hasil penjualan pupuk bokashi sebesar Rp 375.000. Kegiatan pengabdian telah memberikan manfaat positif berupa peningkatan pengetahuan tentang manfaat pupuk bokashi $(87,50 \%)$ dan keterampilan membuat pupuk bokashi $(79,17 \%)$.
\end{abstract}

Kata kunci: pencemaran lingkungan, pupuk bokashi, sapi Bali

\begin{abstract}
Oeletsala Village is an area in Kupang Regency that dominates the community who runs a business of feedlot (paronization) of Bali cattle. Paronization activities were implemented hereditary, but less explored the utilization of livestock waste (feces) causing environmental pollution and supporting the population of flies as a mechanical vector of thelaziasis. This community service aims to improve the knowledge and skills of farmer group partner members related to making bokashi fertilizer. Community service activities are conducted in the Nij Baki Group, which has 24 members. Implementation of activities methods include extension, plot demonstration, assistance, and evaluation. The results of activities achieved were the production of $300 \mathrm{~kg}$ Bokashi fertilizer and the revenue from the sale of Bokashi fertilizer amounted to IDR 375.000. Community service activities have provided positive benefits in the form of increased knowledge about the benefits of Bokashi fertilizer (87.50\%) and skills for making bokashi fertilizer $(79.17 \%)$.
\end{abstract}

Keywords: environmental pollution, bokashi fertilizer, Bali cattle

\section{PENDAHULUAN}

Desa Oeletsala merupakan salah satu desa di Kecamatan Taebenu yang berada dalam wilayah Kabupaten Kupang. Desa Oeletsala memiliki iklim kering yang dipengaruhi angin muson dengan bulan basah (hujan) antara DesemberMaret dan bulan kering (kemarau) antara JuniSeptember (BPS Kabupaten Kupang 2017). Kondisi iklim yang demikian memengaruhi pola bercocok tanam maupun beternak masyarakat. Mata pencaharian utama masyarakat di Desa Oeletsala adalah sebagai petani dan peternak. Jenis-jenis tanaman pertanian yang dikembangkan adalah padi ladang, jagung, ubi kayu, ubi jalar, kacang tanah, kacang hijau, dan jambu mete, sedangkan jenis ternak yang dominan dipelihara adalah sapi Bali, kambing, babi, dan ayam. 
Lokasi kelompok tani Nij Baki (mengandung arti kelompok yang sinergis dalam bahasa Timor) terletak di RT 06, RW 03, Desa Oeletsala, Kecamatan Taebenu, Kabupaten Kupang. Kelompok ini terbentuk sejak tanggal 20 Mei 2006 didasarkan atas ikatan kekeluargaan dan kebersamaan dalam setiap kegiatan pertanian misalnya untuk membuka kebun baru. Salah satu kegiatan usaha di kelompok tani Nij Baki yang berjalan sejak tahun 2009 adalah budi daya sapi potong pola penggemukan yang dalam istilah masyarakat Timor disebut paronisasi. Ternak sapi potong yang dikembangkan adalah sapi Bali dengan jumlah populasi awal 79 ekor. Nalle (2016) menyatakan bahwa ternak sapi potong merupakan komoditas unggulan di Kabupaten Kupang yang mendukung peningkatan PDRB (Produk Domestik Regional Bruto) sebesar 3,01\% dan tambahan lapangan kerja sebesar $44,04 \%$. Usaha ternak sapi potong memberikan kontribusi sebesar $44,15 \%$ dari total pendapatan rumah tangga dibandingkan usaha lahan kebun $27,42 \%$ dan usaha lainnya 20,44\% (Sunarto et al. 2016).

Anggota mitra kelompok tani Nij Baki mempunyai potensi untuk memeroleh penerimaan alternatif dari usaha paronisasi karena saat ini sudah memiliki modal dasar, yaitu sebanyak 108 ekor sapi Bali yang secara fisiologi normal mengeluarkan feses. Ternak sapi tersebut memiliki rata-rata umur di atas dua tahun dengan indikator dua pasang gigi seri susu pada rahang bawah yang telah berganti menjadi gigi permanen. Mengacu pada pendapat Astiti (2018) diketahui bahwa pergantian gigi seri susu tengah bagian dalam menjadi gigi tetap mengindikasikan umur sapi 2,5 tahun. Apabila pengeluaran feses rata-rata $10 \mathrm{~kg} /$ ekor/hari, maka diperoleh 1.080 kg (1,08 ton) per hari. Dengan asumsi pengurangan kadar air sebesar 50\% maka dalam sehari diproduksi sebanyak 0,54 ton feses kering. Huda \& Wikanta (2017) menyatakan bahwa usaha peternakan sapi saat ini belum memaksimalkan pemanfaatan feses secara ekonomis walau tersedia 8-10 kg feses/ekor/hari, 2,6-3,6 ton per tahun atau setara dengan 1,5-2 ton pupuk organik. Gambaran tersebut menunjukkan peluang bagi anggota mitra kelompok tani Nij Baki untuk melakukan pengolahan limbah peternakan sebagai upaya meminimalkan pencemaran lingkungan, menekan populasi lalat, namun dapat menjadi sumber pendapatan.

Terdapat beberapa masalah yang dihadapi oleh anggota mitra kelompok tani Nij Baki dalam usaha paronisasi. Pertama, ternak sapi Bali milik anggota mitra sebagian besar ditambatkan di daerah sumber pakan pada padang penggembalaan, dan dipindahkan lagi ke padang penggembalaan lain apabila ketersediaan rumput alam di daerah tersebut sudah pendek $( \pm 4$ $\mathrm{cm}$ dari tanah). Bahan baku feses pada ternak sapi yang ditambatkan umumnya tersedia dalam jumlah yang bervariasi tergantung lama pemeliharaan di suatu padang penggembalaan. Kedua, aggota mitra lainnya melakukan paronisasi di dalam kandang sederhana yang berpagar kayu namun tidak dilengkapi atap. Pemberian pakan pada ternak sapi di dalam kandang umumnya diletakkan begitu saja di atas tanah atau digantung karena tidak tersedia tempat pakan yang permanen. Bahan baku feses pada ternak sapi yang dikandangkan walaupun tersedia di lokasi namun jarang dikumpulkan karena sudah bercampur dengan sisa pakan atau terinjak oleh kaki ternak sapi (Gambar 1). Kondisi tersebut pada akhirnya memengaruhi palatabilitas, kesehatan ternak, produktivitas sapi Bali, dan pencemaran lingkungan. Dampak selanjutnya adalah waktu paronisasi menjadi lebih lama, yaitu 12-15 bulan. Pada sisi yang lain, anggota mitra kelompok tani Nij Baki juga kurang mendapatkan informasi terkait teknologi pengolahan limbah peternakan.

Berdasarkan analisis situasi, survei pendahuluan dan diskusi bersama anggota mitra kelompok tani Nij Baki disepakati solusi prioritas yang harus diimplementasikan untuk mengatasi permasalahan mitra adalah memanfaatkan feses
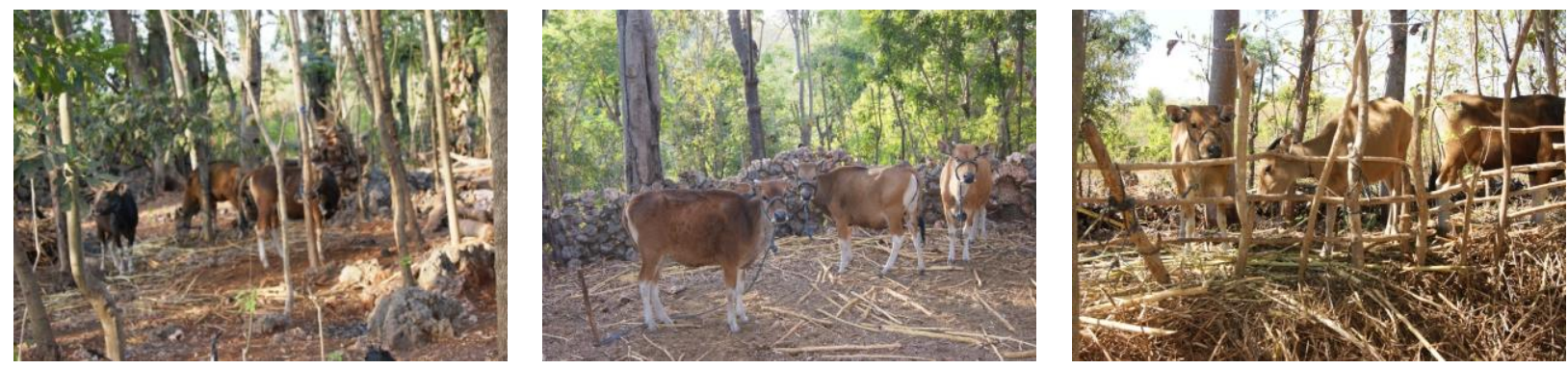

Gambar 1 Sistem pemeliharaan ternak sapi Bali oleh kelompok tani Nij Baki. 
ternak sapi Bali melalui introduksi teknologi pembuatan pupuk bokashi. Kegiatan tersebut diterapkan dengan pendekatan partisipatif kepada anggota mitra kelompok tani. Tujuan umum yang ingin dicapai dalam pengabdian ini adalah mendorong terciptanya sumber penerimaan alternatif dari usaha paronisasi ternak sapi bali dan meminimalkan pencemaran lingkungan. Sedangkan, tujuan khusus yang ingin dicapai adalah peningkatan aspek pengetahuan (kognitif) dan keterampilan (psikomotor) anggota mitra kelompok tani Nij Baki tentang pembuatan pupuk bokashi.

\section{METODE PELAKSANAAN KEGIATAN}

\section{Lokasi dan Partisipan Kegiatan}

Pengabdian masyarakat dilaksanakan di Desa Oeletsala, Kecamatan Taebenu, Kabupaten Kupang. Partisipan yang dilibatkan merupakan anggota mitra kelompok tani Nij Baki berjumlah 24 orang yang diketuai Bapak Nimbrot Meto.

\section{Bahan dan Alat}

Bahan baku utama yang digunakan dalam pembuatan pupuk bokashi adalah feses ternak sapi Bali yang diperoleh dari anggota mitra kelompok tani, dedak padi, arang sekam, gula pasir, air, dan effective microorganism 4 (EM 4). Peralatan utama yang digunakan dalam pelaksanaan survei, identifikasi masalah, dan pembuatan pupuk bokashi meliputi laptop, pita ukur, buku agenda, pulpen, kamera Nikon D3200, sekop merek Carman, timbangan kapasitas $50 \mathrm{~kg}$ merek Camry, termometer, kawat saring, ember, plastik bening, mesin pencacah rumput (chopper), terpal, dan parang.

\section{Metode Pelaksanaan}

Metode pelaksanaan kegiatan pengabdian pada kelompok tani Nij Baki disajikan pada Gambar 2. Berdasarkan Gambar 2 diketahui bahwa identifikasi dan pemecahan masalah mitra dilakukan melalui metode observasi, yaitu dengan mengamati sistem paronisasi yang dilakukan anggota mitra disertai wawancara mendalam terhadap aktivitas paronisasi yang dilakukan. Hasil yang diperoleh adalah uraian masalah-masalah utama mitra dan kesepakatan solusi prioritas yang diimplementasikan dalam menyelesaikan masalah tersebut. Lebih lanjut, tim pelaksana melakukan sosialisasi untuk menginformasikan model kegiatan yang diterapkan kepada anggota mitra selain mengumpulkan data-data yang berkaitan dengan profil anggota mitra kelompok tani.

Metode penyuluhan dan demonstrasi plot (demplot) dilakukan melalui pemberian materi, diskusi, dan praktik pembuatan pupuk bokashi. Kegiatan penyuluhan dan demplot dilaksanakan selama empat minggu, di mana pada minggu ke 3-4 dilakukan demplot pembuatan pupuk bokashi. Cakupan materi kegiatan penyuluhan dan demplot disajikan pada Tabel 1.

Metode pendampingan dilakukan selama tiga bulan setelah proses demonstrasi plot dilaksanakan untuk mengetahui keberlanjutan pembuatan pupuk bokashi secara mandiri oleh anggota mitra, sedangkan evaluasi dilakukan setiap satu minggu setelah materi penyuluhan diberikan dan demplot dilaksanakan. Pendampingan dimaksudkan untuk mengetahui serta menilai perkembangan kegiatan, kesesuaian rencana, dan keberlanjutan pembuatan pupuk bokashi di kelompok tani Nij Baki. Monitoring teknis pemasaran dilakukan untuk memudahkan kegiatan pendampingan, sedangkan evaluasi dinilai dari keaktifan dan partisipasi anggota mitra kelompok tani dalam mengikuti penyuluhan, menyediakan bahan baku produksi, memahami materi pengabdian yang diberikan, serta minat mengembangkan pembuatan pupuk bokashi.

\section{Metode Pengumpulan dan Analisis Data}

Pengumpulan data dalam kegiatan pengabdian dilakukan melalui wawancara mendalam menggunakan kuesioner terhadap tiga aspek penilaian utama, meliputi partisipasi anggota mitra kelompok tani Nij Baki dalam mengikuti kegiatan penyuluhan dan demplot, pemahaman terhadap materi penyuluhan dan demplot yang disampaikan, dan keberlanjutan pemanfaatan

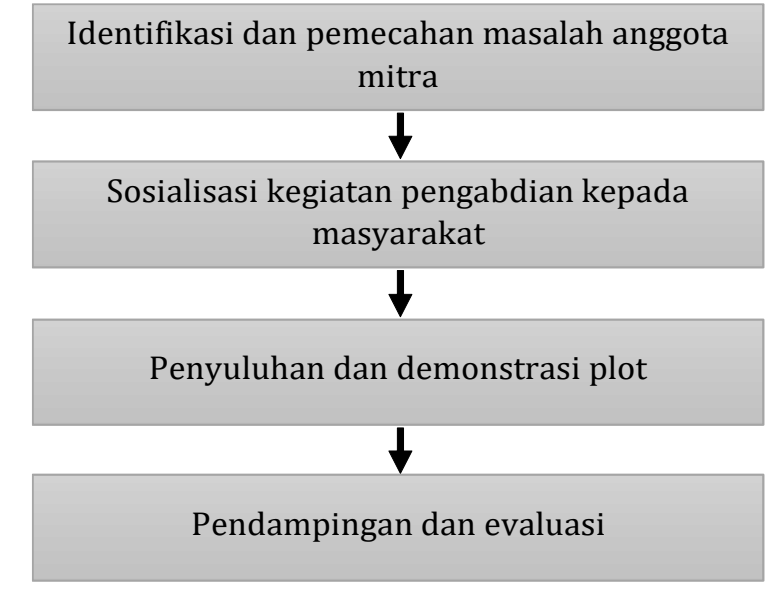

Gambar 2 Metode penyelesaian masalah di kelompok tani Nij Baki. 
Tabel 1 Materi penyuluhan dan demplot dalam kegiatan pengabdian kepada masyarakat

\begin{tabular}{ll}
\hline \multicolumn{1}{c}{ Jenis kegiatan } & \multicolumn{1}{c}{ Deskripsi kegiatan } \\
\hline Manfaat beternak sapi Bali & Materi bertujuan meningkatkan pengetahuan mitra tentang manfaat \\
& beternak sapi Bali sehingga mitra termotivasi untuk terus melakukan \\
& usaha paronisasi. Materi yang diberikan adalah peluang usaha \\
& beternak sapi Bali. Materi diberikan secara lisan (oral), tulisan (leaflet), \\
& dan dilanjutkan dengan diskusi. \\
& Materi bertujuan meningkatkan pengetahuan mitra tentang \\
& pentingnya kandang dalam kegiatan paronisasi serta tipe dan model \\
& kandang sapi. Penyampaian materi secara oral dibantu leaflet. Diskusi \\
& dilakukan setelah penyampaian materi. \\
& Materi bertujuan meningkatkan pengetahuan dan keterampilan mitra \\
& tentang pemanfaatan feses ternak sapi sebagai pupuk bokashi. Materi \\
Pengolahan limbah ternak sapi & diberikan secara oral dan tulisan, dilanjutkan diskusi dan demplot \\
& pembuatan pupuk bokashi. Hasil demplot selanjutnya dipasarkan. \\
& Materi bertujuan meningkatkan pengetahuan dan keterampilan mitra \\
& tentang manfaat ikutan dan nilai ekonomis paronisasi. Materi \\
Nilai ekonomis pemeliharaan sapi & diberikan secara oral dan tulisan, dilanjutkan diskusi dan analisis \\
Bali melalui pola paronisasi & ekonomi sederhana pembuatan pupuk bokashi. \\
\hline
\end{tabular}

teknologi pembuatan pupuk bokashi. Data-data yang dikumpulkan dari aspek penilaian utama selanjutnya ditabulasi dan dianalisis menggunakan metode deskriptif kuantitatif sehingga diperoleh nilai persentase tertinggi dari masingmasing aspek penilaian utama.

\section{HASIL DAN PEMBAHASAN}

\section{Pelaksanaan Kegiatan}

Pelaksanaan kegiatan pengabdian di kelompok tani Nij Baki diawali dengan pembukaan yang dihadiri oleh Kepala Desa Oeletsala. Kegiatan dilakukan di rumah ketua kelompok tani Nij Baki. Materi pembuatan pupuk bokashi dan demplot disampaikan oleh dosen Politani Negeri Kupang yang berpengalaman melakukan pembuatan bokashi. Tim pengabdian, aparat desa, anggota mitra, serta pemateri yang hadir dalam pembukaan kegiatan penyuluhan maupun demplot di kelompok tani Nij Baki terlihat pada Gambar 3.

Hasil wawancara menunjukkan bahwa 87,50\% anggota mitra kelompok tani Nij Baki yang melakukan kegiatan paronisasi berada pada kisaran umur 24-67 tahun, dan rataan umur 47,17 tahun (Gambar 4). Sari (2013) dan Rohaeni et al. (2014) menyatakan bahwa tingkatan usia produktif berada pada kisaran 15-64 tahun sehingga peternak dalam usia produktif memiliki potensi untuk mengembangkan diri dan aktivitas usaha tani.

Berdasarkan Gambar 5 diketahui bahwa lakilaki yang menjadi anggota mitra kelompok tani Nij Baki dominan melakukan usaha paronisasi
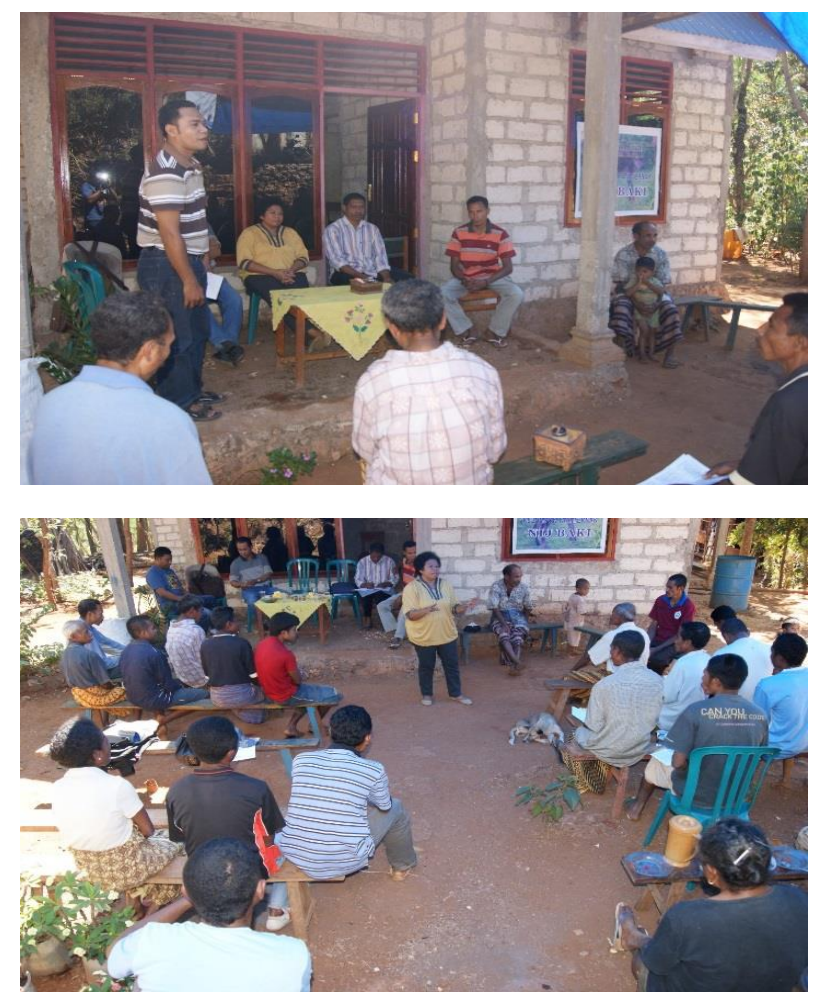

Gambar 3 Pembukaan kegiatan penyuluhan dan demplot di kelompok tani Nij Baki.

$(83,33 \%)$. Hal tersebut selain berkaitan dengan kemampuan bekerja, peran laki-laki sebagai pencari nafkah, juga memiliki hubungan dengan kesulitan mencari pakan pada tempat yang jauh dari lokasi paronisasi. Simanjuntak (2001) menyatakan bahwa laki-laki memiliki tingkat partisipasi kerja yang lebih tinggi dibandingkan perempuan karena merupakan pencari nafkah utama dalam memenuhi kebutuhan keluarga.

Upaya peningkatan produktivitas dan manajemen usaha paronisasi ternak sapi Bali perlu 


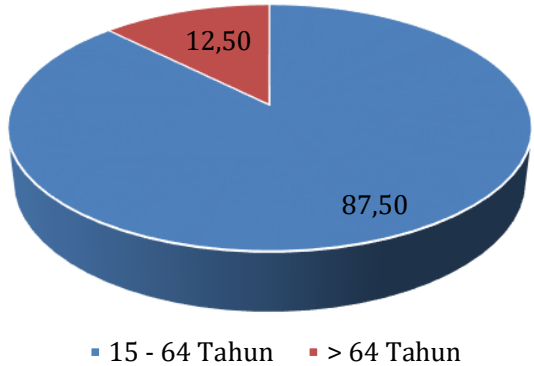

Sumber: Data primer (diolah)

Gambar 4 Distribusi kelompok umur anggota kelompok tani Nij Baki.

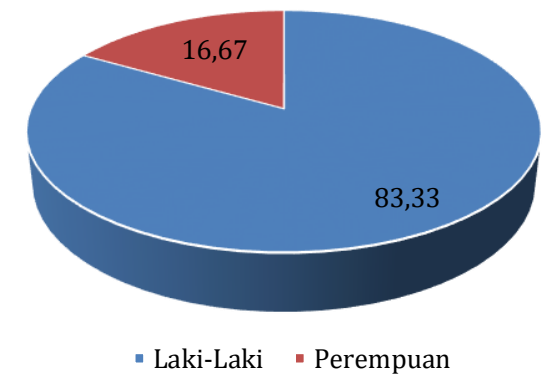

Sumber: Data primer (diolah)

Gambar 5 distribusi jenis kelamin anggota kelompok tani Nij Baki.

didukung oleh pendidikan peternak yang memadai. Berdasarkan Gambar 6 diketahui bahwa distribusi tingkat pendidikan anggota mitra kelompok tani Nij Baki adalah setara SD (58,33\%). Lestariningsih et al. (2008); Wirdahayati (2010) menyatakan bahwa tingkat pendidikan peternak memengaruhi terhadap kemampuan penerapan teknologi. Peternak dengan pendidikan rendah umumnya memiliki kemampuan berpikir yang relatif sempit sehingga sulit menerima inovasi baru, serta cenderung mempraktikkan apa yang telah dilakukan secara turun-temurun. Permasalahan tersebut dapat diatasi dengan melakukan penyuluhan, demonstrasi plot, serta evaluasi penerapan teknologi pembuatan pupuk bokashi di tingkat anggota mitra kelompok tani.

Jangka waktu paronisasi merupakan faktor penting yang memengaruhi pendapatan peternak. Lama kegiatan paronisasi akan memberikan konsekuensi terhadap peningkatan elemen biaya terutama pakan dan tenaga kerja. Hasil wawancara menunjukkan bahwa anggota mitra kelompok tani Nij Baki umumnya melakukan paronisasi $>10$ bulan $(70,83 \%)$. Kondisi tersebut sekaligus menggambarkan bahwa aktivitas paronisasi ternak sapi potong yang dijalankan mitra secara teknis kurang efektif dan secara ekonomis kurang efisien (Gambar 7). Jermias et

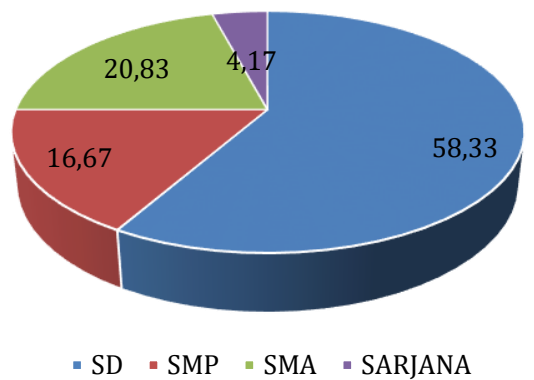

Sumber: Data primer (diolah)

Gambar 6 Distribusi tingkat pendidikan anggota kelompok tani Nij Baki.

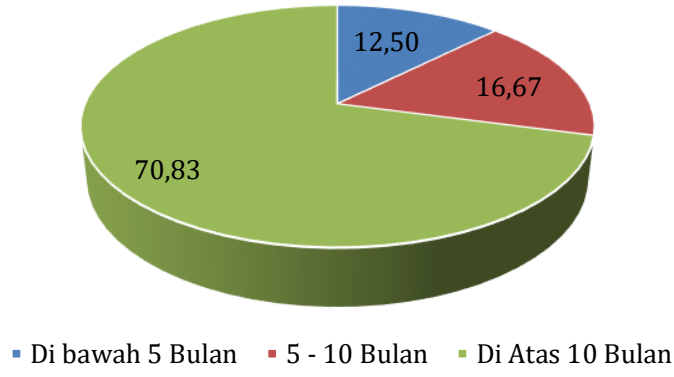

Sumber: Data primer (diolah)

Gambar 7 Distribusi jangka waktu paronisasi ternak sapi Bali pada kelompok tani Nij Baki.

al. (2010) menyatakan bahwa lamanya jangka waktu paronisasi pada ternak sapi potong disebabkan oleh penggunaan bakalan yang masih berusia sekitar 1 tahun sehingga pertumbuhan yang terjadi belum optimal. Syafrial et al. (2007) menyatakan bahwa lama penggemukan dalam kisaran 4-10 bulan sangat bergantung kepada kondisi awal dan bobot sapi yang digemukkan.

\section{Pembuatan Pupuk Bokashi}

Pengolahan limbah ternak sapi Bali melalui pembuatan pupuk bokashi pupuk kandang didahului kegiatan penyuluhan dan dilanjutkan dengan demplot sebagai salah satu alih teknologi dalam pembelajaran orang dewasa. Melalui penyuluhan dan demplot, diharapkan terjadi peningkatan pengetahuan dan keterampilan anggota dalam menjalankan usaha paronisasi teristimewa dalam memanfaatkan feses sapi Bali sebagai sumber pendapatan alternatif (Gambar 7). Nur et al. (2000) menyatakan bahwa peningkatan kegiatan penyuluhan, pelatihan, dan demplot merupakan bagian dari fokus pengembangan sumber daya manusia yang penting diperhatikan dalam pengembangan usaha peternakan rakyat. Dampak positif pengolahan feses sapi selain dimanfaatkan sebagai pupuk, secara sinergis juga bermanfaat untuk menekan 
populasi lalat yang berpengaruh terhadap penurunan prevalensi thelaziasis pada ternak tersebut. Wirawan et al. (2018) menyatakan bahwa sisa pakan dan akumulasi feses merupakan lingkungan yang ideal bagi perkembangbiakan lalat sehingga populasinya meningkat. Populasi lalat yang meningkat memengaruhi tingginya prevalensi thelaziasis karena lalat bertindak sebagai hospes intermedier dalam siklus hidup cacing tersebut. Demplot pembuatan pupuk bokashi yang diterapkan pada sasaran anggota mitra kelompok tani Nij Baki dapat dilihat pada Gambar 8.

Prosedur pembuatan pupuk bokashi adalah sebagai berikut:

- EM 4, gula pasir, dan air dicampur dalam ember sampai merata dan diamkan \pm 15 menit

- Feses, arang sekam, dan dedak padi dicampurkan secara merata

- Larutan hasil campuran EM 4, gula pasir, dan air dipercik secara merata ke dalam bahan campuran feses, arang sekam, dan dedak padi hingga kandungan air berkisar 30-40\%, ditandai tidak adanya tetesan air apabila campuran dikepal dengan tangan dan apabila dilepas campuran tetap tampak menggumpal

- Semua campuran (bahan a, b, dan c) selanjutnya ditutup menggunakan terpal agar
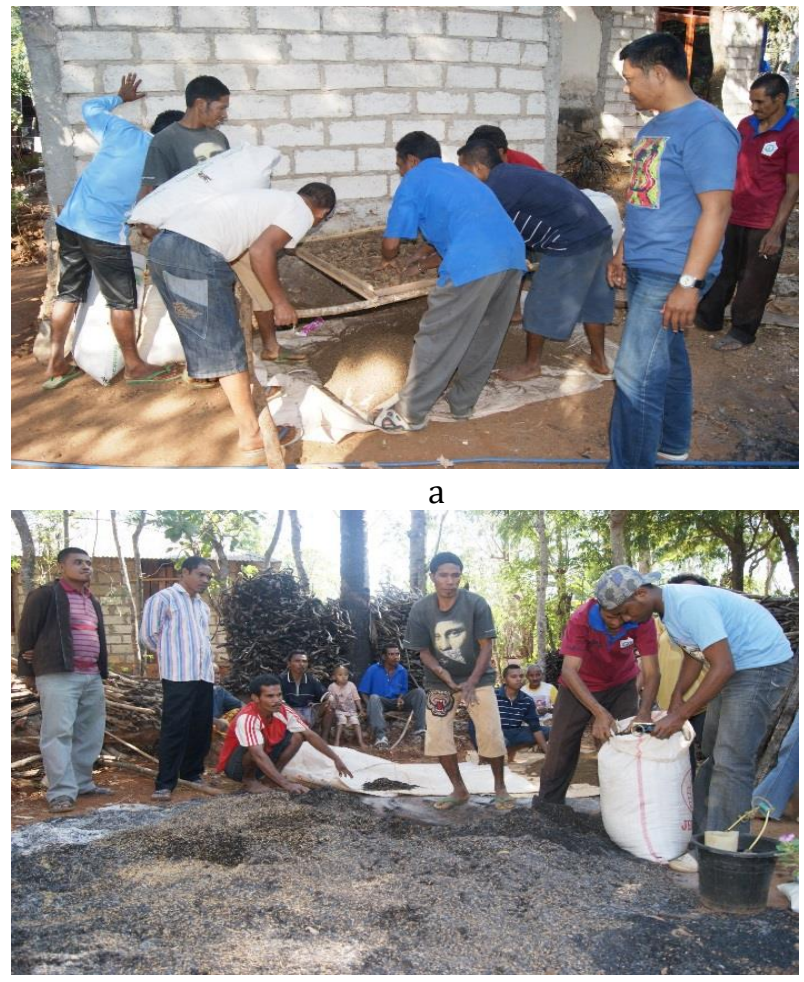

C terhindar dari air/hujan dan sinar matahari langsung, dan diletakkan di atas lantai setelah sebelumnya diberi alas setinggi $15-20 \mathrm{~cm}$

- Suhu tumpukan pupuk bokashi yang ideal antara $40-50^{\circ} \mathrm{C}$. Pengukuran suhu dilakukan setiap 5 jam sekali atau maksimal setiap hari. Apabila suhu $>50^{\circ} \mathrm{C}$ maka penutup bahan (terpal) harus dibuka dan tumpukan bahan harus di bolak balik. Hal tersebut disebabkan karena suhu yang terlampau tinggi akan merusak mikroorganisme sehingga pembusukan menjadi lebih cepat

- Proses fermentasi pupuk bokashi berlangsung 4-7 hari

- Sesudah hari ke-7 terpal harus dibuka dan pupuk bokashi yang sudah jadi didiamkan pada suhu ruangan untuk selanjutnya dikemas dan diberi label

- Pupuk bokashi yang telah matang dan siap digunakan memiliki ciri-ciri berwarna hitam, gembur, tidak panas, dan tidak berbau. Tim pelaksana pengabdian melakukan pendampingan agar pupuk bokashi yang dihasilkan dapat dipasarkan secara baik dan menarik. Pendampingan tersebut melalui kegiatan labelling, pengemasan, dan penetapan harga jual pupuk bokashi berdasarkan perhitungan ekonomi (Gambar 9).
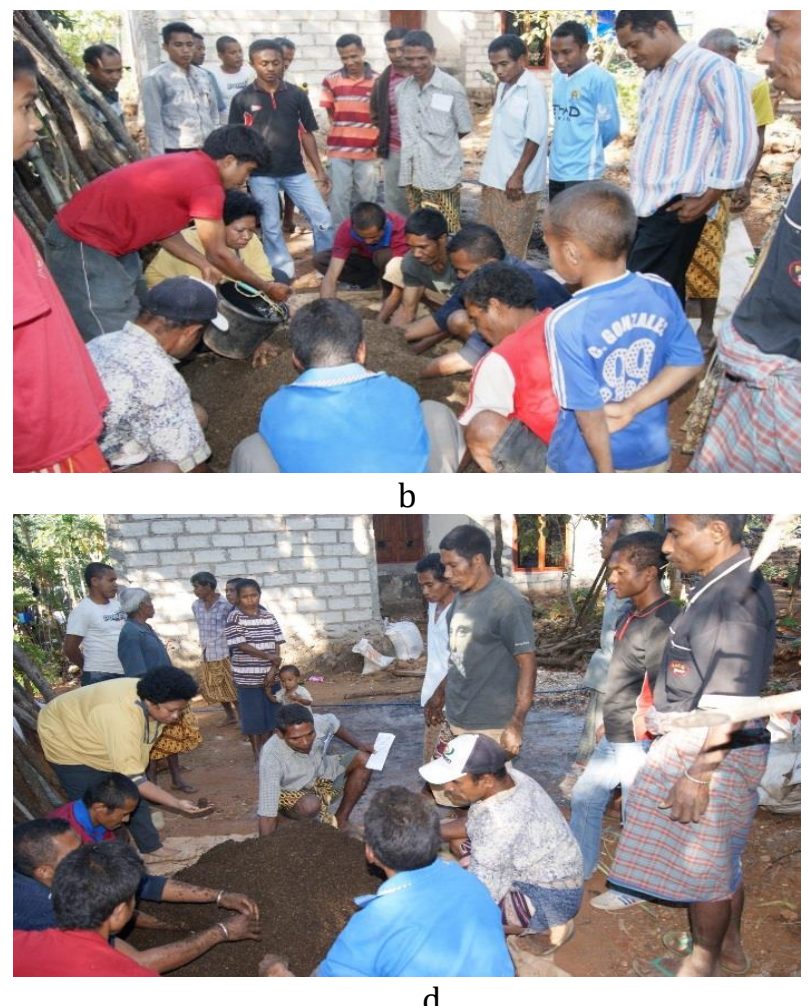

d

Gambar 8 Demplot pembuatan pupuk bokashi yang diterapkan pada kelompok tani Nij Baki; a) Pengayakan dan sortasi feses; b) Pencampuran bahan baku; c) Penyiraman campuran larutan EM4, gula pasir dan air; dan d) Pemeriksaan adonan pupuk bokashi yang telah selesai dibuat. 


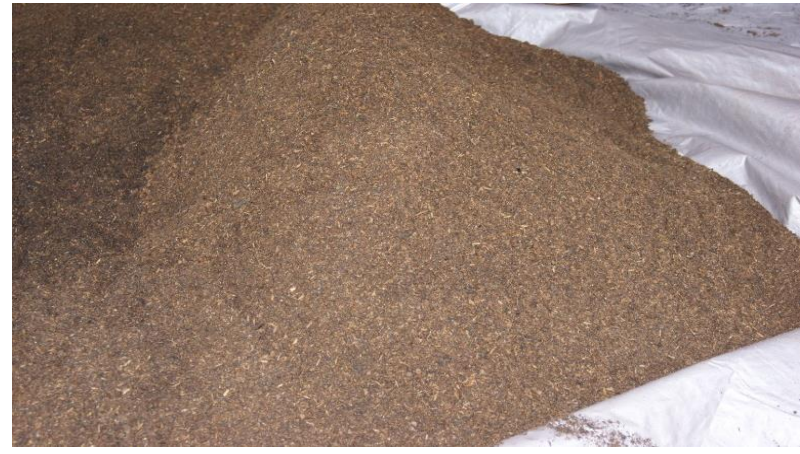

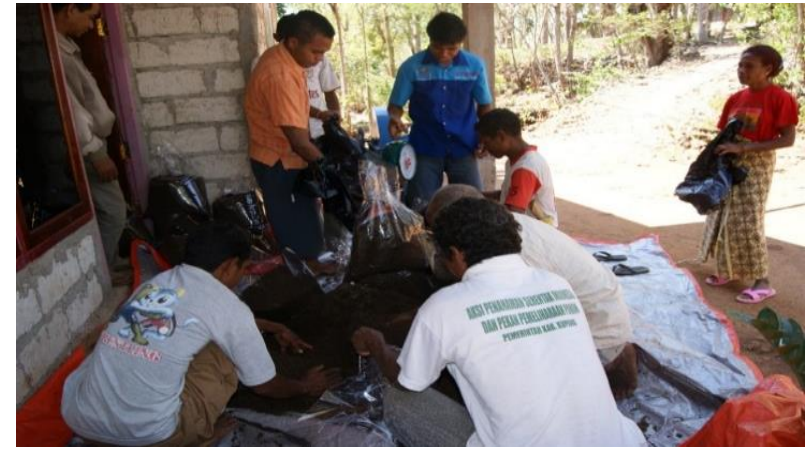

b

Gambar 9 Pendampingan pengemasan pupuk bokashi; a) Penampilan fisik pupuk bokashi siap kemas dan b) Penimbangan dan pengemasan pupuk bokashi

\section{Analisis Hasil Kegiatan}

Hasil kegiatan pengabdian di kelompok tani Nij Baki dilakukan analisis berdasarkan tiga aspek penilaian sebagaimana terdapat dalam kuesioner, yaitu partisipasi anggota mitra, pemahaman materi penyuluhan, dan keberlanjutan pemanfaatan teknologi. Analisis dilakukan terhadap 24 anggota mitra kelompok tani. Hasil analisis ditampilkan pada Tabel 2. Berdasarkan Tabel 2 diketahui bahwa anggota mitra kelompok tani Nij Baki mempunyai partisipasi aktif dalam mengikuti kegiatan penyuhan dan demplot, yaitu sebanyak 91,67\%. Namun demikian, keterlibatan aktif untuk mengumpulkan feses ternak sapi Bali sebagai bahan baku pembuatan pupuk bokashi masih rendah dan hanya dilakukan oleh $58,33 \%$ anggota mitra kelompok tani. Hal tersebut selain disebabkan oleh tersebarnya feses pada berbagai lokasi di padang penggembalaan serta bercampurnya feses dengan sisa pakan, juga dipengaruhi oleh peralihan musim hujan ke musim kemarau yang mengakibatkan kesulitan dalam mengumpulkan feses kering. Pengaruh musim pancaroba juga dialami dalam kegiatan pengabdian yang dilakukan oleh Nugraha (2016).

Berkaitan dengan pemahaman terhadap materi kegiatan, sebanyak $87,50 \%$ anggota mitra kelompok tani mengetahui manfaat pupuk bokashi, namun belum semua anggota memahami tahapan pembuatan pupuk bokashi $(70,83 \%)$. Rendahnya pemahaman ini disebabkan karena anggota mitra kelompok tani sebelumnya kurang mengetahui teknologi pengolahan feses sapi menjadi pupuk bokashi $(37,51 \%)$ pada saat dilakukan wawancara pra-penyuluhan. Anggota mitra umumnya hanya mengandalkan pupuk anorganik untuk menunjang keperluan pemupukan tanaman palawijanya. Indikator yang digunakan untuk penilaian peningkatan keterampilan adalah observasi langsung pada saat demplot pembuatan pupuk bokashi yang masih harus dibimbing oleh tim pelaksana pengabdian kepada masyarakat $(79,17 \%)$.

Anggota mitra kelompok tani Nij Baki mendapatkan manfaat dari pembuatan pupuk bokashi untuk keperluan pupuk organik maupun sumber pendapatan alternatif. Namun demikian, keinginan mengembangkan pupuk bokashi masih rendah (62,50\%). Hal tersebut diduga berkaitan dengan masih rendahnya jumlah dan frekuensi pembuatan pupuk bokashi di tingkat anggota mitra kelompok tani sehingga belum terlihat signifikan dalam memengaruhi pendapatan.

\section{Kendala yang Dihadapi}

Kegiatan pengabdian masyarakat di kelompok tani Nij Baki mengalami kendala dalam hal penyediaan bahan baku feses. Hal tersebut selain disebabkan oleh musim pancaroba, juga dipengaruhi oleh pola paronisasi ternak sapi bali yang dilakukan $54,17 \%$ anggota mitra melalui sistem tambat berpindah sehingga feses tersebar di beberapa lokasi penggembalaan dan tidak terkumpul pada satu tempat. Kendala lain yang dialami 45,83\% anggota mitra berkaitan dengan sebagian besar feses telah bercampur dengan batang kayu sisa limbah leguminosa pakan atau terinjak oleh kaki ternak sapi yang dikandangkan.

\section{Dampak dan Upaya Keberlanjutan Kegiatan}

Dampak yang dihasilkan dari kegiatan penyuluhan dan demplot di kelompok tani $\mathrm{Nij}$ Baki adalah dihasilkannya $300 \mathrm{~kg}$ pupuk bokashi yang dikemas dalam plastik $5 \mathrm{~kg}$, diberi label nama kelompok tani, serta dipasarkan (Gambar 10). Pupuk bokashi tersebut berasal dari tujuh karung feses (setara dengan $350 \mathrm{~kg}$ ) yang dikumpulkan oleh 14 orang anggota mitra kelompok tani. Faktor yang berpengaruh terhadap pengurangan jumlah bahan dasar feses 
Tabel 2 Analisis hasil pelaksanaan kegiatan pengabdian di kelompok tani Nij Baki

\begin{tabular}{lcc}
\hline \multicolumn{1}{c}{ Aspek penilaian } & Jumlah (orang) & Persentase (\%) \\
\hline Partisipasi dalam kegiatan & & \\
\hline Mitra terlibat aktif dalam kegiatan penyuluhan dan demplot & 22 & 91,67 \\
Mitra terlibat mengumpulkan bahan baku pupuk bokashi & 14 & 58,33 \\
\hline Pemahaman materi kegiatan & 19 & 79,17 \\
\hline Mitra memahami materi penyuluhan yang disampaikan & 17 & 70,83 \\
Mitra mengetahui tahapan pembuatan pupuk bokashi & 21 & 87,50 \\
Mitra mengetahui manfaat pupuk bokashi & 19 & 79,17 \\
Mitra mempraktikkan pembuatan pupuk bokashi & 20 & 83,33 \\
Mitra mengetahui fungsi EM-4 untuk pembuatan pupuk bokashi & & \\
\hline Keberlanjutan pemanfaatan teknologi & 15 & 62,50 \\
\hline Mitra berkeinginan mengembangkan usaha pembuatan pupuk bokashi & & \\
sebagai sumber pendapatan alternatif rumah tangga & 21 & 87,50 \\
Mitra mendapatkan manfaat dari pembuatan pupuk bokashi & &
\end{tabular}

disebabkan karena sebelum ditimbang, dilakukan sortasi dengan mengeluarkan batu-batu kerikil atau ranting pakan yang tercampur di dalamnya untuk selanjutnya dilakukan proses pembuatan pupuk bokashi dengan campuran berbagai bahan baku. Hasil dari pembuatan pupuk bokashi oleh tim pelaksana dan anggota mitra kelompok tani ditetapkan dengan harga jual Rp 1.250/kg sehingga diperoleh penerimaan sebesar Rp 375.000/proses produksi. Berdasarkan penerimaan tersebut, diketahui keuntungan dalam satu proses produksi pupuk bokashi di kelompok tani $\mathrm{Nij}$ Baki adalah sebesar $\mathrm{Rp}$ 150.450 .

Keberlanjutan kegiatan ditunjukkan dari ketertarikan maupun komitmen anggota mitra kelompok tani Nij Baki untuk melanjutkan pembuatan pupuk bokashi. Hal tersebut disepakati menggunakan teknik arisan, di mana setiap bulannya anggota mitra secara bersama-sama dan sukarela mengumpulkan feses sapi lalu diolah menjadi pupuk bokashi. Uang hasil penjualan pupuk bokashi pada saat demonstrasi plot disepakati menjadi simpanan kas kelompok yang digunakan untuk pembelian bahan baku sebagai biaya produksi pembuatan pupuk bokashi secara mandiri oleh anggota mitra kelompok tani (Gambar 11).

\section{SIMPULAN}

Pengabdian kepada masyarakat yang dilakukan di kelompok tani Nij Baki memberikan pengalaman empirik, manfaat, dan perubahan hasil positif terkait introduksi teknologi pembuatan pupuk bokashi. Hal tersebut diketahui melalui peningkatan pengetahuan tentang

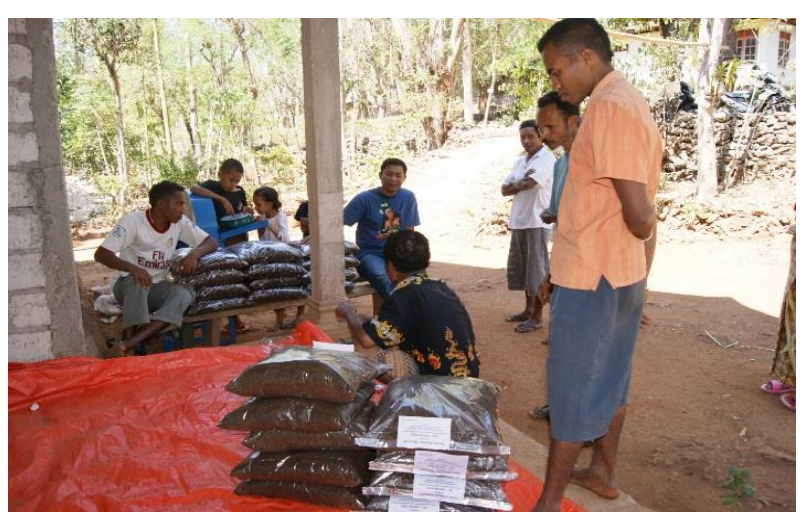

Gambar 10 Pemberian label pupuk bokashi kemasan 5 kg oleh kelompok tani Nij Baki.

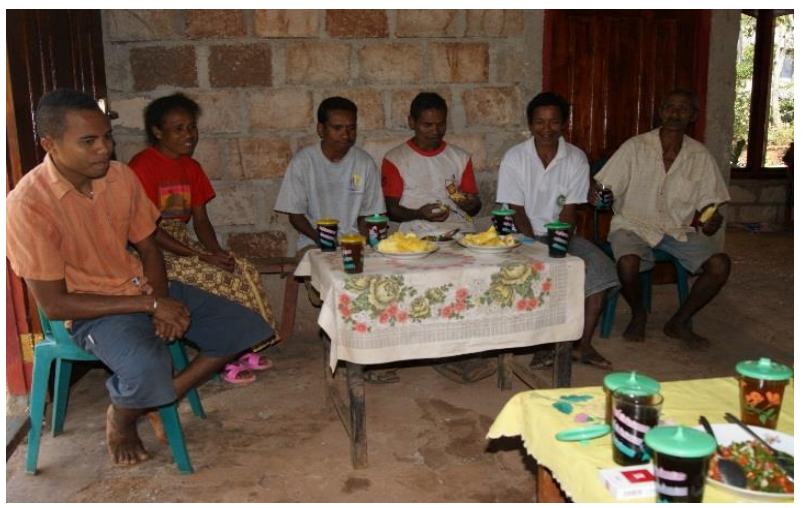

Gambar 11 Evaluasi proses dan hasil kegiatan di kelompok tani Nij Baki.

manfaat pupuk bokashi, keterampilan membuat pupuk bokashi, dihasilkannya $300 \mathrm{~kg}$ pupuk bokashi yang dikemas secara baik, serta penerimaan sebesar Rp 375.000 dari hasil penjualan pupuk bokashi. Manfaat lainnya adalah terwujudnya kerja sama anggota mitra kelompok tani Nij Baki dalam merancang arisan pembuatan pupuk bokashi sebagai usaha alternatif yang dilakukan untuk memanfaatkan feses ternak sapi Bali. 


\section{UCAPAN TERIMA KASIH}

Terima kasih diucapkan kepada Direktorat Riset dan Pengabdian Masyarakat Kemenristek Dikti atas dukungan pembiayaan pelaksanaan kegiatan. Terima kasih yang sama juga disampaikan kepada Kepala Unit P2M Politeknik Pertanian Negeri Kupang atas dukungannya sehingga kegiatan pengabdian kepada masyarakat dapat berjalan sebagaimana mestinya, dan kepada anggota mitra kelompok tani Nij Baki atas partisipasinya dalam penyediaan bahan, penyuluhan, demplot, dan pemasaran pupuk bokashi.

\section{DAFTAR PUSTAKA}

Astiti NMAGR. 2018. Sapi Bali dan Pemasarannya. Denpasar (ID): Warmadewa University Press.

[BPS] Badan Pusat Statistik Kabupaten Kupang. 2017. Kabupaten Kupang dalam Angka. Katalog BPS: 1102001.5303.

Huda S, Wikanta W. 2017. Pemanfaatan Limbah Kotoran Sapi Menjadi Pupuk Organik sebagai Upaya Mendukung Usaha Peternakan Sapi Potong di Kelompok Tani Ternak Mandiri Jaya Desa Moropelang Kecamatan Babat Kabupaten Lamongan. Aksiologiya: Jurnal Pengabdian kepada Masyarakat. 1(1): 26-35. https://doi.org/10.30651/aks.v1i1.303

Jermias JA, Tulle DR, Leo Penu C, Jelantik IGN. 2010. Tingkat Pendapatan Peternak pada Penggemukan Sapi Bali dengan Sistem Bagi Hasil di Kabupaten Kupang. Partner. 17(1): 43-50.

Lestariningsih M, Basuki, Endang Y. 2008. Peran Serta Wanita Peternak Sapi Perah dalam Meningkatkan Taraf Hidup Keluarga. Ekuitas. 12(1): 121-141. https://doi.org/10.24034/ j25485024.y2008.v12.i1.2069

Nalle MN. 2016. Analisis Efisiensi Teknis Sapi Potong di Kabupaten Lamongan. Agrimor: Jurnal Agribisnis Lahan Kering. 1(3): 57-59. https://doi.org/10.32938/ag.v1i03.252

Nugraha AW. 2016. Pemberdayaan Kelompok Tani dalam Pembuatan Pupuk Organik Cair Ramah Lingkungan dari Bahan Baku Hayati. JADIMAS. 5(1): 10-15.
Nur S, Djatmiko OE, Zubaidah S. 2000. Pengembangan Industri Peternakan Rakyat Mandiri melalui Penguatan Kelembagaan dan Pemberdayaan SDM. Animal Production. 2(2): 60-68.

Rohaeni ES, Hartono B, Fanani Z, Nugroho BA. 2014. Sustainability of Cattle Farming using Analysis Approach of Structural Equation Modeling (A Study on Dry Land of Tanah Laut Regency, South Kalimantan, Indonesia). International Journal of Agronomy and Agricultural Research (IJAAR). 4(1): 8-21.

Sari AM. 2013. Kinerja Penyuluh Pertanian dalam Pengembangan Usaha Peternakan Sapi Bali di Kabupaten Muna Provinsi Sulawesi Selatan. [Tesis]. Denpasar (ID): Universitas Udayana.

Simanjuntak PJ. 2001. Pengantar Ekonomi Sumber Daya Manusia. Edisi Kedua. Jakarta (ID): Lembaga Penerbit Fakultas Ekonomi Universitas Indonesia.

Sunarto E, Nono OH, Lole UR, Henuk YL. 2016. Kondisi Ekonomi Rumah Tangga Peternak Penggemukan Sapi Potong pada Peternakan Rakyat di Kabupaten Kupang. Jurnal Peternakan Indonesia. 18(1): 21-28. https://doi.org/10.25077/jpi.18.1.2128.2016

Syafrial, Susilawati E, Bustami. 2007. Manajemen Pengelolaan Penggemukan Sapi Potong. Jakarta (ID): Balai Pengkajian Teknologi Pertanian, Departemen Pertanian.

Wirawan IGKO, Semang A, Mullik ML. 2018. Prevalensi Thelaziasis pada sapi Bali (Bos Sondaicus) dengan Sistem Pemeliharaan Semi Intensif di Desa Tanah Putih, Kecamatan Kupang Timur. Dalam: Prosiding Seminar Nasional Peternakan Berkelanjutan Berbasis Lahan Kering 4. Kupang (ID): Universitas Nusa Cendana. Halaman: 167-171.

Wirdahayati RB. 2010. Kajian Kelayakan dan Adopsi Inovasi Teknologi Sapi Potong Mendukung Program PSDS: Kasus Jawa Timur dan Jawa Barat. Dalam: Prosiding Seminar Nasional dan Veteriner. Bogor (ID): Pusat Penelitian dan Pengembangan Peternakan. Halaman: 339-346. 